\title{
КОНЦЕПТУАЛЬНІ ЗАСАДИ ПІДГОТОВКИ МАЙБУТНІХ УЧИТЕЛІВ ДО ТЬЮТОРСЬКОЇ ДІЯЛЬНОСТІ
}

\section{К. П. Осадча}

Мелітопольський державний педагогічний університет імені Богдана Хмельницького

вул. Гетьманська, 20, м. Мелітополь, 72312, Україна. E-mail: okp@mdpu.org.ua

Представлено авторську концепцію підготовки майбутніх учителів до тьюторської діяльності в інформаційно-комунікаційному освітньому середовищі закладу вищої освіти. Подано правові положення Концепції, ії̈ провідна ідея, теоретичне (закони, закономірності, дидактичні принципи) та методологічне (підходи, мета, завдання, організаційно-педагогічні умови) підгрунтя підготовки майбутніх учителів до тьюторської діяльності в інформаційно-комунікаційному освітньому середовищі закладу вищої освіти із урахуванням сучасного стану і тенденцій розвитку суспільства й освіти. Концепція грунтується на антропологічному, індивідуальному, особистісно-орієнтованому, системному, діяльнісному, компетентнісному, ресурсному, модульному та міждисциплінарному методологічних підходах. Підготовка майбутніх учителів до тьюторської діяльності в інформаційнокомунікаційному освітньому середовищі має на меті поетапне формування тьюторської компетентності як необхідної складової професіоналізму майбутнього вчителя. Автором визначено шляхи професійної підготовки майбутніх учителів до тьюторської: поступова, професійна та науково-професійна підготовка, неформальна та інформальна освіта.

Ключові слова: концепція; майбутній учитель; тьюторська діяльність; підготовка тьютора; освітнє середовище.

\section{КОНЦЕПТУАЛЬНЫЕ ОСНОВЫ ПОДГОТОВКИ БУДУЩИХ УЧИТЕЛЕЙ К ТЬЮТОРСКОЙ ДЕЯТЕЛЬНОСТИ}

\section{Е. П. Осадчая}

Мелитопольский государственный педагогический университет имени Богдана Хмельницького

ул. Гетманская, 20, г. Мелитополь, 72312, Украина. E-mail: okp@ mdpu.org.ua

Представлена авторская концепция подготовки к тьюторской деятельности будущих учителей в информационно-компьютерной образовательной среде высшего ученого заведения. Подано правовые положения Концепции, ее основная идея, теоретическое (законы, закономерности, дидактические принципы) и методологическое (подходы, цели, задачи, организационно-педагогические условия) основы подготовки к тьюторской деятельности будущих учителей в информационно-компьютерной образовательной среде высшего ученого заведения с учетом современного состояния и тенденций развития общества и образования. Концепция основывается на антропологическом, индивидуальном, личностно-ориентированном, системном, деятельностном, компетентностном, ресурсном, модульном и междисциплинарном методологических подходах. Подготовка будущих учителей к тьюторской деятельности в информационно-коммуникационной образовательной среде имеет целью поэтапное формирование тьюторской компетентности как необходимой составляющей профессионализма будущего учителя. Автором определены пути профессиональной подготовки будущих учителей к тьюторской деятельности: постепенная, профессиональная и научно-профессиональная подготовка, неформальное и информальное образование.

Ключевые слова: концепция; будущий учитель; тьюторская деятельность; подготовка тьютора; образовательная среда.

АКТУАЛЬНІСТЬ РОБОТИ. У сучасних умовах підвищення соціальної і культурної ролі освіти інтелектуально-творчий і культурний потенціал суспільства значною мірою залежить від якості підготовки педагогічних кадрів. При цьому на перший план виходить гуманістичний підхід до навчання з урахуванням новітніх наукових досліджень у сфері антропології, педагогіки та психології. Одним з основних завдань сучасної освіти сьогодні є розвиток індивідуальності самого учня, його здібностей, самостійності та самосвідомості, врахування його індивідуальних особливостей у процесі навчання. Педагогіка партнерства та особистісно-орієнтований підхід, на яких акцентовано увагу в Концепції нової української школи (2016), актуалізують нову роль учителя - не як єдиного наставника та джерело знань, а як коуча, фасилітатора, тьютора, модератора в індивідуальній освітній траєкторії дитини [1].

В умовах індивідуалізації освіти та особистісноорієнтованого підходу учитель має здійснювати тью- торську діяльність, яка полягає у створенні умов для того, щоб учень сам свідомо міг обирати мету своєї освіти, формулювати свої освітні запити та максимально використовувати різноманітні освітні ресурси для побудови і реалізації своєї індивідуальної освітньої програми. Учитель має вміти організовувати освітній процес як тьютор: будувати навчання на постійному рефлексивному співвіднесенні досягнень учня (сьогодення і минулого) з його інтересами і прагненнями (образ майбутнього); створювати надмірне освітнє середовище, насичене безліччю пропозицій, які потенційно можуть бути цікаві учню; супроводжувати його рух у цьому просторі пропозицій, обговорюючи при цьому різні стратегії [2].

Завдяки стрімкому поширенню інформаційнокомунікаційних технологій у вчителів зростає можливість використовувати відкритий доступ до корисних знань та організовувати надмірне освітнє середовище у мережі Інтернет. За таких умов провідною фігурою у шкільному навчанні стає учитель, який 
може поєднати сучасні вимоги до індивідуалізації освіти та реалізації особистісно-орієнтованого підходу з можливостями інформаційно-комунікаційних технологій у освітньому процесі. Тому найважливішим напрямом у підготовці майбутніх учителів стає створення умов, що формують філософію їх професійної діяльності, сприяють розвитку суб'єктності й індивідуальності їх особистості, стимулюють до саморозвитку та самовдосконалення в умовах стрімкого розвитку інформаційно-комунікаційних технологій. Адже лише вчитель, здатний до самопізнання, саморозкриття, самореалізації та рефлексії, може стимулювати відповідні процеси в своїх учнях, розвиваючи їх індивідуальні властивості та здійснюючи їх підготовку до успішного життя в умовах інформаційного суспільства. Отже необхідно здійснювати підготовку майбутніх учителів до тьюторської діяльності в інформаційно-комунікаційному освітньому середовищі.

Певне підгрунтя для концептуального підходу до проблеми професійної підготовки майбутніх учителів до тьюторської діяльності створено дослідженнями зарубіжних і вітчизняних вчених. Зокрема науковцями висвітлено питання формування педагогічної майстерності та творчості (Н.В. Гузій, I.А. Зязюн, С.О. Сисоєва), професійної підготовки майбутніх учителів в умовах закладів вищої освіти (В.Г. Бевз, О.М. Семеног, М.Г. Чобітько), системного підходу до підготовки майбутніх учителів (Л.В. Коваль, Н.В. Морзе, В.В. Осадчий [3], Л.О. Хомич), використання інформаційнокомунікаційних технологій у професійній підготовці майбутніх учителів (А.М. Коломієць, С.М. Смирнова-Трибульська). Окремі аспекти тьюторської діяльності досліджували М.В. Іващенко, Т.І. Койчева, А.К. Сучану. Особливості тьюторства подано у роботах таких зарубіжних науковців як Дж.К. Кітченс (J.C. Kitchens) [5], Ч.P. Натсон (Ch.R. Natson), Е. Хейс (Е. Науs). Окремі аспекти підготовки педагогів до тьюторської діяльності висвітлювали такі Е.Е. Гордон (Е.E. Gordon) [4], П.С. Коскінен (P.S. Koskinen), С. Ріфорт (S. Riffort)та ін.. Проте системного і грунтовного бачення стратегії підготовки майбутніх учителів до тьюторської діяльності в інформаційно-комунікаційному освітньому середовищі науковцями не представлено.

Метою статті є теоретико-методологічне обгрунтування концептуальних засад підготовки майбутніх учителів до тьюторської діяльності в інформаційнокомунікаційному освітньому середовищі.

МАТЕРІАЛ I РЕЗУЛЬТАТИ ДОСЛІДЖЕНЬ. Концепція підготовки майбутніх учителів до тьюторської діяльності в інформаційно-комунікаційному освітньому середовищі (далі Концепція) являє собою систему теоретико-методологічних положень щодо підготовки студентів галузі 01 «Освіта/Педагогіка» до професійної діяльності в умовах індивідуалізації та варіативності освіти,відкритості та надмірності інформаційних освітніх ресурсів.

Правову основу Концепції становлять положення чинного законодавства України та інших нормативних правових актів, що регламентують вищу і середню освіту, стосуються питань інформатизації осві- ти та тьюторської діяльності, а саме: Закон України «Про Національну програму інформатизації» (2015), Наказ МОН «Про проведення дослідноекспериментальної роботи на базі загальноосвітніх навчальних закладів України з темою «Тьюторська технологія як засіб реалізації принципу індивідуалізації в освіті» (2015), Наказ «Про затвердження Положення про індивідуальну форму навчання в загальноосвітніх навчальних закладах» (2016), Наказ $\mathrm{MOH}$ «Про проведення всеукраїнського експерименту з упровадження науково-педагогічного проекту «Школа тьюторської майстерності» (2016), Розпорядження Кабінету міністрів України «Про схвалення Концепції реалізації державної політики у сфері реформування загальної середньої освіти «Нова українська школа» на період до 2029 року» (2016), Закон України «Про Освіту» (2017), Закон України «Про загальну середню освіту» (2017), Закон України «Про вищу освіту» (2017), Проект «Концепції розвитку педагогічної освіти» (2018).

Концепція грунтується на методологічних підходах до професійної підготовки майбутніх учителів, що висвітлюються у наукових і методичних працях Ш.А. Амонашвілі, І.М. Богданової, Н.В. Гузій, Т.М. Десятова, О.А. Дубасенюк, В.Ф. Заболотного, І.А. Зязюна, Л.В. Коваль, А. М. Коломієць, М.Г. Криловець, О.М. Куцевол, М.О. Лазарєва, С.П. Миронової, Н.В. Морзе, В.Г. Моторіної, О.М. Семеног, О.П. Сергєєнкової, С.О. Сисоєвої, О.В. Суховірського, Л.О. Хомич, Л.Л. Хоружої, М.Г. Чобітька, O.I. Шапран, П.Г. Щедровицкого та ін., а також ідеях індивідуалізації (П.Ф. Каптерєв[6],С.Ю. Ніколаєв, В.О. Онищука, О.Я. Савченко) та тьюторства (К.О. Алєксандрова, А.М. Бойко, Е. О’Брайант, Е. Гордон, Д.Ю. Гребьонкіна, В.М. Кухаренко, Т.М. Ковальова, Ю.А. Лях, А.В. Ніколаєва, В.С. П'янін, С.Ф. Сіроткін, А.К. Сучану, О.О. Челнокова, Н.О. Шалімова).

Концепція визначає провідну ідею, закони та закономірності, методологічні підходи та дидактичні принципи, мету, завдання, організаційно-педагогічні умови підготовки майбутніх учителів до тьюторської діяльності в інформаційно-комунікаційному освітньому середовищі вищого навчального закладу iз урахуванням сучасного стану і тенденцій розвитку суспільства й освіти.

Провідна ідея підготовки майбутніх учителів до тьюторської діяльності в інформаційнокомунікаційному освітньому середовищі вищого навчального закладу полягає у тому, що вона має здійснюватися з урахуванням: соціального замовлення, що відображається у вимогах до тьюторської компетентності; загальних психолого-педагогічних, методичних і технологічних вимогах до навчальнометодичних та інформаційних ресурсів підготовки майбутніх учителів до тьюторської діяльності, що відображається у змісті підготовки, застосованих формах, методах, засобах та технологіях навчання й контролю, спрямованих на формування тьюторської компетентності. Особливістю підготовки майбутніх учителів до тьюторської діяльності є те, що учитель інформатики, який володіє тьюторською компетентністю, у школі може виконувати тьюторські функ- 
ції у роботі з учнями та одночасно бути лідероморганізатором (тьютор-наставник) тьюторської діяльності інших учителів. Отже підготовка майбутніх учителів до тьюторської діяльності має включати два вектори: один спрямований на підготовку до тьюторсьої діяльності з учнями у ході професійної діяльності (реалізація індивідуального підходу у навально-виховному процесі школи), а другий спрямований на підготовку до організації освітньоінформаційного педагогічного співтовариства 3 метою здійснення тьюторського супроводу учнів (рис. 1).

Підготовка майбутніх учителів інформатики до тьюторської діяльності в інформаційно-комунікаційному освітньому середовищі

\begin{tabular}{|c|c|c|}
\hline Вектор 1 & & Вектор 2 \\
\hline Тьютор учнів & Ролі & Тьютор-наставник \\
\hline $\begin{array}{l}\text { • } \quad \text { розробка і супровід індивідуальної } \\
\text { освітньої програми учнів } \\
\text { • } \quad \text { створення умов для індивідуалізації } \\
\text { освіти } \\
\text { • } \quad \text { допомога у розкритті та розвитку зді- } \\
\text { бностей, талантів і можливостей кожної } \\
\text { дитини на основі партнерства між учите- } \\
\text { лем, учнем і батьками }\end{array}$ & Функції & $\begin{array}{l}\bullet \quad \text { розробка і управління проектами (ме- } \\
\text { неджмент проектів) для співпраці з учителя- } \\
\text { ми,учнями, батьками } \\
\bullet \quad \text { співпрацювати з колегами з метою ор- } \\
\text { ганізації ефективного тьюторського супрово- } \\
\text { ду учнів } \\
\text { • } \quad \text { розробляти і заохочувати використання } \\
\text { ІКТ у тьюторській діяльності, мотивувати } \\
\text { колег вчитися один в одного }\end{array}$ \\
\hline
\end{tabular}

Рисунок 1 - Вектори підготовки майбутніх учителів інформатики до тьюторської діяльності в інформаційно-комп'ютерному освітньому середовищі

Концепція спирається на поняттєвотермінологічний апарат тьюторства (тьютор, тьюторант, тьюторський супровід, тьюторство, тьюторська діяльність, компетентність, індивідуальна освітня траєкторія, індивідуальна освітня програма, індивідуальний освітній маршрут) та поняття у галузі інформаційних технологій (інформаційнокомунікаційне освітнє середовище, інформаційнокомунікаційні технології, платформа дистанційного навчання), сучасні вимоги до професійної підготовки майбутніх учителів в Україні та за кордоном, аналізі практичного досвіду підготовки майбутніх учителів до тьюторської діяльності в Україні та за кордоном.

Підготовка майбутніх учителів до тьюторськоі діяльності у Концепції представлена як поетапне формування загальних та фахових компетентностей майбутнього учителя у насиченому інформаційнокомунікаційному освітньому середовищі за допомогою вивчення доцільного змісту, застосування комплексу форм, методів, засобів та технологій навчання тьюторській діяльності, вирішення професійно орієнтованих завдань (вправ).

Підготовка майбутніх учителів до тьюторської діяльності - процес, ознаками якого є системність, цілісність, диференційованість, поетапна організація, практико орієнтованість та студентоцентрованість. Сутність процесу професійної підготовки визначається через поняття системи і характеризується єдністю змісту, форм, методів, засобів, технологій, спрямованих на результат (формування тьюторської компетентності) й утворюючих цю систему.

Теоретичною основою Концепції слугують зако- ни, що мають свій вияв у більшості освітньовиховних систем: закон соціальної зумовленості цілей, змісту, принципів і методів навчання; закон розвивального і виховного впливу навчання; закон зумовленості результатів навчання особливостями діяльності й спілкування студентів; закон цілісності та єдності педагогічного процесу; закон взаємозв'язку та єдності теорії і практики в навчанні; закон взаємозв'язку і взаємозумовленості індивідуальної групової й колективної навчальної діяльності [7].

Процес професійної підготовки майбутніх учителів до тьюторської діяльності, маючи у своїй структурі процеси навчання, виховання, освіти, професійної підготовки й розвитку, постає самостійним цілісним явищем, що має свої закономірності. Як педагогічному процесу йому властиві такі найзагальніші закономірності: закономірності мети навчання, які залежать від рівня й темпу розвитку суспільства, його можливостей і потреб, від того, наскільки розвинута педагогічна теорія і практика; закономірності змісту навчання, що випливають із загальної мети й цілей навчання, темпів соціального та науково-технічного прогресу, вікових та індивідуальних можливостей студента, матеріальнотехнічної бази навчальних закладів; закономірності управління процесом навчанням визначаються інтенсивністю й зв'язками у системі навчання, обгрунтованістю корекційних впливів; закономірності методів навчання залежать від знань і навичок педагогів у застосуванні методів, мети і змісту навчання, віку й можливостей студентів, організації навчального процесу; закономірності стимулювання навчання залежать від внутрішніх і зовнішніх стимулів (моти- 
вів) навчання; закономірності якості навчання пов'язані з попередньо досягнутими результатами, характером і обсягом навчального матеріалу, організаційно-педагогічною взаємодією між педагогом та студентами [7].

Основними положеннями, що виражають залежність між цілями професійної підготовки майбутніх учителіві закономірностями, що спрямовують практику навчання у ВН3, у Концепції є принципи, що охоплюють дидактичний процес вищої школи й педагогічну систему з іiї елементами: цілеспрямованості і науковості навчання; доступності навчання, урахування вікових та індивідуальних особливостей студентів; принцип гуманізації навчання; єдності освітніх, розвивальних і виховних функцій навчання; забезпечення органічної єдності теоретичної і практичної підготовки фахівців вищої кваліфікації; активності та творчої самостійності студентів і їх відповідальності за результати навчальнопізнавальної діяльності; принцип систематичності і послідовності у процесі навчальної діяльності викладача і самостійної роботи студента; поєднання конкретного й абстрактного у навчальному процесі вищої школи; міцності знань, умінь і навичок, розвитку розумових сил студентів [8].

Концепція грунтується на таких методологічних підходах: антропологічному, індивідуальному, особистісно-орієнтованому, системному, діяльнісному, компетентнісному, ресурсному, модульному, міждисциплінарному.

У Концепції ми виходимо $з$ того, що антропологічний niдxiд полягає в тому, що, з одного боку, в процесі самореалізації розкриваються й використовуються людиною власні індивідуальні можливості, формується індивідуальність як певне динамічне особистісне утворення, а з іншого, самореалізація $\epsilon$ функціональною ознакою індивідуальності [9]. Це реалізується у особливих вимогах до змісту, методів i організації навчання майбутніх учителів, яке представлено не стільки як педагогічно адаптований соціальний досвід, а як власний індивідуальний досвід «спроби побудови себе нового» (Т.М. Ковальова). Здійснювана у такому руслі підготовка має буде варіативною, демократичною, студентоцентрованою (людиноцентрованою), особистісно-орієнтованою, грунтуватися на поєднанні традиційних та інноваційних форм, методів, засобів і технологій навчання.

Реалізація індивідуального підходу, за якого центральною проблемою постає розвиток особистості та іiі індивідуальності, передбачає оформлення індивідуального освітнього плану та маршруту майбутніх учителів з урахуванням того, що вони зможуть рухатися за ними, якщо будуть мати можливість обирати оптимальні форми і темпи навчання, цікавий для них зміст, застосовувати способи навчання, що найбільш відповідають їх індивідуальним особливостям, рефлексивно усвідомлювати отримані результати та здійснювати оцінку і коригування своєї пізнавальної діяльності. У ході навчального процесу визнається неповторність та унікальність особистості студента, його творчих, інтелектуальних чи інших особливостей, а також необмежених можливостей для його саморозвитку. Це ви- магає від викладача тьюторської позиції, яка передбачає роботу з процесами індивідуалізації через реалізацію тьюторської діяльності та здійснення функції супроводу і підтримки. Таким чином, студенти на прикладі роботи викладача усвідомлять аспекти тьюторської діяльності й основні шляхи реалізації тьюторських функцій у процесі навчання.

Цінність індивідуального підходу до підготовки майбутніх учителів полягає у тому, що він дає можливість на основі виявлення особистіснопрофесійних рис студентів, їх життєвого і професійного досвіду та здібностей, індивідуальних вікових та психологічних особливостей врахувати їх персональні мотиви, потреби, інтереси у підготовці до тьюторської діяльності. Це дозволяє розробити індивідуальну освітню програму та спрогнозувати індивідуальний освітній маршрут кожного студента і запланувати засоби впливу на підготовку до тьюторської діяльності.

У Концепції особистісно-орієнтований підхід, робить головними завдання становлення і розвитку особистісних властивостей суб'єктів освіти (студентів і викладачів), розвиток їх особистісного досвіду. Однак, як зазначав I.А. Зязюн, «особистість - досить складна система якостей і характеристик, яка включена в різні види діяльності, звідси гостра необхідність системного і діяльнісного підходів, їх методології, технології реалізації» [10].

Системний підхід до пізнання і перетворення будь-якого об'єкта є провідним загальнонаукових підходом і являє собою напрям методології спеціально-наукового пізнання і педагогічної практики, в основі якого лежить дослідження об'єктів як систем. Системний підхід застосовувався у Концепції для розгляду підготовки майбутніх учителів до тьюторської діяльності як цілісної системи філософських ідей, педагогічних законів, закономірностей і принципів, методологічних підходів, організаційнопедагогічних умов та інформаційно-комунікаційних засобів іiі забезпечення в умовах вищого навчального закладу. Структурно-системний підхід дозволив виділити компоненти тьюторської компетентності (загальні та фахові компетентності), формування яких $є$ системотвірним чинником у підготовці майбутніх учителів до тьюторської діяльності як цілісної педагогічної системи.

Важливим у процесі підготовки майбутніх учителів до тьюторської діяльності є діяльнісний підхід, у ракурсі якого особистість розглядається як суб'єкт діяльності, яка формуючись у діяльності й у спілкуванні з іншими людьми, визначає характер цієї діяльності й спілкування. У Концепції передбачається, що цей підхід сприяє всебічному розвитку особистості майбутнього вчителя у процесі підготовки, а також включенню цієї особистості у тьюторську діяльність (як опосередковано через діяльність педагога, так і безпосередньо на практиці через власні проби цієї діяльності), яка відповідатиме інтересам і здібностям студента. Врахування інтересів і здібностей майбутніх учителів здійснюється через зміст i форму самих навчальних занять, через характер спілкування та види навчальних діяльностей. Таким чином, у процесі навчальної діяльності здійснювати- 
меться не лише врахування індивідуальнопсихологічних особливостей студентів, а й формування та подальший розвиток їх психіки, пізнавальних процесів, якостей особистості, діяльнісних характеристик тощо. Діяльнісний підхід передбачає створення умов для оволодіння такими зразками і способами мислення і діяльності, які б сприяли кваліфікованій професійній та успішній тьюторській діяльності та для розвитку пізнавальних сил і творчого потенціалу особистості майбутнього вчителя. Він також орієнтує викладача на установку, що найважливіший фактор розвитку і самовизначення студента - його активна пізнавальна та комунікативна діяльність. Тому спонукання до активної пізнавальної діяльності, набуття практичного досвіду тьюторства, мотивування до оволодіння тьюторською компетентністю у процесі підготовки є важливими завданнями викладача у рамках діяльнісного підходу.

Використання компетентнісного підходу спричинено тим, що у центрі його уваги - взаємозв'язок очікувань майбутньої чи реалізованої професійної діяльності 3 функціональними характеристиками суб'єктів цієї діяльності [10]. На ньому грунтується виявлення змісту складових тьюторської компетентності та оцінювання динаміки зміни рівня тьюторської компетентності майбутніх учителів у процесі іiі формування у закладі вищої освіти. Перелік обраних компетентностей відображає сукупність завдань, необхідність вирішення яких може виникнути в професійній діяльності, веде до «метакомпетентності» як цілісної характеристики майбутнього учителя, який володіє необхідними можливостями вирішення найрізноманітніших задач тьюторської діяльності. В умовах компетентнісного підходу метою підготовки майбутніх учителів до тьюторської діяльності $є$ формування сукупності загальних і фахових компетентностей, що входять у структуру тьюторської компетентності.

3 позиції ресурсного підходу [11] розглядається процес підготовки майбутніх учителів до тьюторської діяльності, який передбачає залучення зовнішніх і внутрішніх (індивідуальних) ресурсів студента та покликаний забезпечувати приріст і розвиток його індивідуальних психологічних ресурсів. До зовнішніх ресурсів відносять знання викладача, засоби масової інформації, технічні засоби навчання, електронні ресурси, підручники, лабораторії і т.д. Внутрішні $є$ багаторівневою системою біогенетичних, фізіологічних, психологічних ресурсів. Біогенетичні ресурси залежать від спадковості; до фізіологічних відносять стан здоров'я, особливості будови організму, вік, стать, фізичну витривалість та ін.; психологічні пов'язані з інтелектуальним розвитком, особливостями мотиваційної та емоційної сфер, вольовими характеристиками особистості.

В умовах інформатизації вищої педагогічної освіти в самих різних напрямах і видах освітньої та організаційно-педагогічної діяльності активно можуть бути використані електронні ресурси та ресурси мережі Інтернет. По-перше, для підвищення ефективності лекційних, семінарських і практичних занять студентів. По-друге, для активізації самостійної роботи студентів, особливо в системі навча- льно-дослідницької та науково-дослідницької діяльності. Тому у процесі підготовки майбутніх учителів до тьюторської діяльності доцільним є застосування інформаційно-комунікаційного освітнього середовища із широким (надмірним) вибором різноманітних ресурсів. Їх можна згрупувати за широтою охоплення на внутрішні університетські (електронні навчальні засоби та матеріали й електронні навчально-методичні комплекси викладачів, ресурси бібліотеки університету, професійні гуртки, спецкурси за вибором, тренінги, конференції, семінари, тьюторіали, творчі заходи), ресурси міста (міські бібліотеки, заклади позашкільної та додаткової освіти, культурно-масові заходи, міські конференції та форуми, виставки), глобальні ресурси (ресурси професійних асоціацій, тьюторські форуми, ресурси мережі Інтернет). У результаті підготовки, коли викладач пропонує роботу із широким спектром різноманітних ресурсів для задоволення навчальних потреб майбутніх учителів, вони вчаться використовувати методи роботи з ними у майбутній тьюторській діяльності.

Найбільш ефективним підходом до організації навчального процесу майбутніх учителів, вважаємо модульний niдxiд, який дозволяє на першому етапі освоїти теоретичний матеріал та початкові навички тьюторської діяльності, на другому - отримати досвід практичної діяльності в ролі тьютора у роботі зі студентами (тьюторство ровесників) або дітьми (тьюторство у школах, закладах додаткової чи позашкільної освіти), а на третьому - виконати саморефлексію набутого досвіду під час звітних конференцій з практики, виступів на науково-методичних семінарах чи науково-практичних конференціях.

Важливим у процесі підготовки майбутніх учителів до тьюторської діяльності вважаємо міждисциплінарний niдxid. Через те, що тьютор у своїй професійній діяльності реалізує функції не лише учителя-предметника, але й психолога, соціального педагога, вихователя, організатора та методиста, підготовка майбутніх учителів має бути орієнтована не на вузькоспеціалізовану підготовку, а повинна передбачати міждисциплінарний контекст. Тобто у процесі вивчення дисциплін майбутнім учителям слід створити умови для реалізації зв'язків міжрізними науками. Враховуючи положення міждисциплінарного підходу [12] у підготовці майбутніх учителів до тьюторської діяльності під час вивчення дисциплін психолого-педагогічного циклу буде доцільним включити вивчення теоретичних та практичних блоків з оволодіння арсеналом форм, методів, прийомів, технік і змістом роботи по реалізації тьюторського супроводу, зокрема у рамках самостійного дистанційного навчання.

Підготовка майбутніх учителів до тьюторської діяльності в інформаційно-комунікаційному освітньому середовищі має на меті поетапне формування тьюторської компетентності (загальні і фахові компетентності) як необхідної складової професіоналізму майбутнього вчителя, який у структурі шкільної освіти може здійснювати тьюторську діяльність 3 учнями, зокрема і в умовах дистанційного навчання. Ця мета конкретизується у таких завданнях: 
1. Сформувати вміння здійснювати мотивування та активізацію пізнавального процесу підопічних (учнів, тьюторантів), емоційно-вольовий вплив на них.

2. Сформувати вміння здійснювати індивідуальні та групові форми роботи з підопічним(ими), виконувати завдання індивідуалізації.

3. Підготувати студентів до самооцінювання та рефлексії.

4. Сформувати здатність будувати освітній процес на основі інформаційно-комунікаційних технологій, організовувати навчання мінімально вдаючись до лекційної форми занять та репродуктивних методів навчання.

5. Сформувати вміння використовувати форми, методи, засоби та технології розробки і супроводу індивідуальної освітньої програми підопічного(их)

6. Здійснити розвиток вміння студентів постійно працювати над собою, самоудосконалюватися, підвищувати майстерність.

7. Підготувати майбутніх учителів до реалізації комунікативних процесів з підопічними та у рамках тьюторської діяльності (з батьками, колегами, експертами тощо).

8. Сформувати вміння організувати свою діяльність як тьютора і діяльність тьюторанта 3 метою досягнення його індивідуальних освітніх цілей.

9. Сформувати здатність до здійснення наукових досліджень у сфері тьюторської діяльності.

10. Підготовка до ролей, що освоюються тьютором у процесі роботи у школі (тьютор у класі, тьютор інклюзивного навчання, тьютор дистанційного навчання, тьютор-наставник).

Спираючись на теоретичні засади підготовки майбутніх учителів до тьюторської діяльності ([2], [13]) та аналіз зарубіжного досвіду підготовки до тьюторської діяльності [14] ці завдання можливо виконати завдяки виконанню таких організаційнопедагогічних умов:

1. Відбір, структурування та верифікація змісту підготовки майбутніх учителів до тьюторської діяльності та демократизація освітнього процесу (визнання результатів формальної, неформальної та інформальної освіти).

2. Узгодженість форм, методів, засобів та технологій навчання 3 метою формування тьюторської компетентності майбутніх учителів.

3. Функціонування єдиного інформаційнокомунікаційного освітнього середовища для підготовки майбутніх учителів до тьюторської діяльності.

4. Дотримання ідей практико орієнтованого навчання, що базується на основі впровадження різних видів тьюторства (тьюторство ровесників, академічне тьюторство, тьюторство на виробництві, тьюторство у дистанційному навчанні) у процес підготовки майбутніх учителів до тьюторської діяльності та вирішенні професійно орієнтованих завдань (вправ) різного рівня складності відповідно до сутності та змісту тьюторської діяльності.

5. Впровадження студентоцентрованого навчання, що базується на виявленні індивідуальних особливостей студентів та їх врахуванні у індивідуальній освітній програмі.
Для підготовки майбутніх учителів до тьюторської діяльності необхідне створення таких умов у вищому навчальному закладі, які б сприяли розвитку особистісних та професійних якостей майбутніх учителів при засвоєнні компонентів змісту педагогічної освіти відповідно до їх здібностей, нахилів, цілей професійного становлення, визначення індивідуальної програми професійного зростання та отримання високого рівня професіоналізму в освітньому середовищі 3 використанням інформаційнокомунікаційних технологій.

На сонові аналізу наукових джерел [2], [4], [5], [13] визначено, що професійна підготовка майбутніх учителів до тьюторської діяльності може здійснюватися у ЗВО п’ятьма шляхами:

1) через поступову підготовку під час навчання на бакалавраті у процесі вивчення окремих тем та дисциплін, присвячених тьюторській проблематиці, та проходженні навчальної практики;

2) через професійну підготовку в педагогічних закладах вищої освіти за освітньо-кваліфікаційним рівнем магістр під час вивчення спецкурсів за вибором;

3) через науково-професійну підготовку в педагогічних закладах вищої освіти за освітньокваліфікаційним в аспірантурі під час написання наукових робіт з дослідження тьюторства;

4) через неформальну освіту завдяки участі майбутніх учителів у стажуванні, обміні досвідом, семінарах, конференціях, тренінгах, тьюторіалах, організованих як у ЗВО, в якому вони навчаються, так і за його межами;

5) через інформальну освіту в сертифікаційних чи тренінгових центрах 3ВО, в якому навчаються студенти, чи інших провайдерів освітніх послуг.

Успіх реалізації розробленої Концепції значною мірою визначається рівнем конструктивних відносин, які складаються між адміністративноуправлінськими одиницями (деканати) та професорсько-викладацьким складом. Тому пріоритетним напрямом у реалізації цієї Концепції є формування активного конструктивної взаємодії між організаторами та суб'єктами освітнього процесу.

Етапи реалізації Концепції:

1. Перший етап (підготовчий) - розробка тем у змісті навчальних дисциплін бакалаврату, навчальних курсів для магістрантів та організація семінарів для студентів та викладачів 3 теорії та практики тьюторства.

2. Другий етап - дидактичне забезпечення підготовки до тьюторської діяльності; формування електронної бібліотеки закладу вищої освіти і використання ресурсів відкритих електронних бібліотек у мережі Інтернет; надання допомоги студентам в оволодінні механізмами саморегуляції у самостійному дистанційному навчанні; моделювання професійної підготовки майбутніх учителів до тьюторської діяльності.

3. Третій етап (апробація викладання окремих блоків дисциплін) - реалізація пілотних проектів викладання окремих дисциплін і дослідження сприйняття студентами нової форми навчання, виявлення найбільш істотних труднощів реалізації 
Концепції, коректування технології, змісту чи структури курсів та методів роботи у інформаційноосвітньому середовищі.

4. Четвертий етап - реалізація моделі професійної підготовки майбутніх учителів до тьюторської діяльності; забезпечення навчально-методичної бази процесу професійної підготовки майбутніх учителів до тьюторської діяльності.

5. Визначення ефективності організаційнометодичних умов професійної підготовки до тьюторської діяльності у педагогічному закладі вищої освіти.

Успіх реалізації розробленої Концепції значною мірою визначається рівнем конструктивних відносин, які складаються між адміністративноуправлінськими одиницями (деканати) та професорсько-викладацьким складом. Тому пріоритетним напрямом у реалізації цієї Концепції $є$ формування активного конструктивної взаємодії між організаторами та суб'єктами освітнього процесу.

ВИСНОВКИ. Сформульовані вище концептуальні засади підготовки майбутніх учителів до тьюторської діяльності містять правові положення, провідну ідею, теоретичне та методологічне підгрунтя підготовки майбутніх учителів до тьюторської діяльності в інформаційно-комунікаційному освітньому середовищі закладу вищої освіти із урахуванням сучасного стану і тенденцій розвитку суспільства й освіти. Концепція має такі основні риси:1) комплексність - інтегрує в собі теоретичні та практичні здобутки, отримані різними вченими i практиками, що дає можливість спрямувати положення Концепції на виконання головної цілі: сформувати тьюторську компетентність, достатню для здійснення тьюторського супроводу учнів середньої школи; 2) практична спрямованість - Концепція націлена на використання вже існуючих педагогічних ідей, методологічних підходів та форм, методів і засобів навчання, інформаційний ресурсів та як простір для напрацювання практичних навичок тьюторської діяльності використовує інформаційнокомунікаційне середовище; 3) системність - всі складові частини Концепції узгоджені між собою та відповідають теоретико-методологічним основам підготовки майбутніх учителів до тьюторської діяльності. На основі теоретико-методологічного аналізу літературних джерел визначено шляхи професійної підготовки майбутніх учителів до тьюторської у ЗВО (поступова, професійна та науково-професійна підготовка, неформальна та інформальна освіта).

Перспективними напрямами дослідження вважаємо апробацію та аналіз результатів впровадження запропонованої Концепції підготовки майбутніх учителів до тьюторської діяльності в інформаційнокомп'ютерному освітньому середовищі.

\section{ЛІТЕРАТУРА}

1. Нова українська школа. Концептуальні засади реформування середньої школи. URL: http://nus.org.ua/wp-content/uploads/2017/07/ konczepcziya.pdf (дата звернення: 07.07.2018)

2. Профессия «тьютор»/ Ковалева Т. М. и др.. М.-Тверь : «СФК-офис», 2012. 246 с.

3. Осадчий В. В. Система інформаційнотехнологічного забезпечення професійної підготовки майбутніх учителів в умовах педагогічного університету : монографія / за ред. С. О. Сисоєвої. Мелітополь : Вид. будинок ММД, 2012. 418 с.

4. Gordon E., Morgan R.R., O’Malley Ch.J., Ponticell J. The tutoring revolution. Applying Research for Best Practices, Policy Implications, and Student Achievement. New York: R\&L Education, 2007. 162 p.

5. Kitchens J. C. The Postdisciplinarity of Lore: Professional and Pedagogical Development in a Graduate Student Community of Practice. Doctoral Dissertation. Georgia State University.Atlanta, 2012. $164 \mathrm{p}$.

6. Герасименко Л. В. Ідея індивідуалізації навчання в теорії П. Каптерєва. Вісник Кременчуцького національного університету імені Михайла Остроградського. 2015. Вип. 1 (2). С. 24-31.

7. Ортинський В. Л. Педагогіка вищої школи : навч. посіб. К.: Центр учбової літератури, 2009. 472 с.

8. Туркот Т. І. Педагогіка вищої школи : навч. посібн. К. : Кондор, 2011. 628 с.

9. Рибалко Л.С. Акмеологічні засади професійнопедагогічної самореалізації майбутнього вчителя : автореф. дис... д-ра пед. наук : спец. 13.00.04 «Теорія і методика професійної освіти». Харків, 2008. 44 c.

10. Зязюн І. А. Філософія педагогічної дії : монографія. Черкаси : Вид. від. ЧНУ імені Богдана Хмельницього, 2008. 608 с.

11. Цецорина Т. А. Организация образовательного процесса в школе на основе ресурсного подхода : дис. ... канд. пед. наук : 13.00.01. Белгород, 2002. 172 с.

12. Сисоєва С. О. Методологія міждисциплінарних досліджень у сфері освіти: роб. навч. прогр. для спеціальності 8.18010020 «Управління навчальним закладом» (освітньо-кваліфікаційний рівень «магістр»). К. : [Київ. ун-т ім. Б. Грінченка], 2014. 56 с.

13. Тьютор в образовательном пространстве : учеб. пособ. / под ред. В.П. Сергеевой. М. : ИнфраM, 2016. 192 c. www.dx.doi.org/10.12737/17329.

14. Осадча К. Огляд зарубіжного досвіду формування тьюторської компетентності. Професійна підготовка фахівця в контексті потреб сучасного ринку праці: матер. II Всеукр. наук.-практ. Інтернет-конф. 2017. C. 188-191.

\section{K. Osadcha}

\section{THE CONCEPT OF TRAINING TEACHERS FOR THE TUTORING ACTIVITY}

Bogdan Khmelnitsky Melitopol State Pedagogical University

vul. Hetmanskaya, 20, Melitopol, 72312, Ukraine. E-mail: okp@mdpu.org.ua

Purpose. Tarticle aims to substantiate the conceptual principles of preparing future teachers for tutoring activities in the information and communication educational environment accordingly to the current state and trends of social development and education. Methodology. The scientific methods of analysis, generalization, description and comparison 
have been used in order to determine the conceptual framework to preparing future teachers for tutoring. Findings. The article presents the author's concept of training teachers to be for the tutoring activity in the informational and computer educational environment of a higher educational institution. The legal provisions of the Concept, its main idea, the theoretical (laws, regularities, didactic principles) and methodological (approaches, purposes, tasks, organizational and pedagogical conditions) as the basis for training teachers to be for the tutoring activity are highlighted. Originality. The peculiarity of this training is that the teacher, who has the tutor competence, can perform tutorial functions while working with students and, at the same time, be the leader and the organizer of the tutorial activity for teachers of other subjects. Therefore, the training teachers for tutoring activity should include two vectors: the first is to be aimed at preparing for tutoring with students in the course for professional activity (realization of an individual approach in educational and school process), while the another is aimed at preparing for the organization of educational and informational pedagogical community to the purpose of carrying out the tuition supporting students. Practical value. The research results can be used at preparing educational programs for the training of tutors by providers of educational services. This material will be interesting for the researchers in the fields of theory and methodology for professional education, tutoring, training to teacher. Conclusions. Training teachers to be for the tutoring activity in the Concept is presented as the gradual formation of general and professional competences for the teachers to be in a rich informational and computer education environment by means of studying the expedient content, application at a complex of forms, methods, means and technologies of teaching tutor activity, oriented tasks (exercises). The Concept is based on such methodological approaches as anthropological, individual, person-oriented, systematic, activity-based, competence-based, resourcebased, modular, and interdisciplinary ones. The author defines the ways of professional training for future teachers of tutoring: gradual, professional and scientific-professional training, informal and informal education.

Keywords: concept; teacher to be; tutoring activity; training of tutor; educational environment.

\section{REFERENCES}

1. Nova ukrainska shkola. Kontseptualni zasady reformuvannia serednoi shkoly [New Ukrainian School. Conceptual Principles of Reforming High School], available at: http://nus.org.ua/wp-content/uploads/2017 /07/konczepcziya.pdf (accessed 14.04.2019).

2. Kovaleva, T. M., Kobyshcha, E. I., Popova (Smolik), S. Y., Terov, A. A., Cheredilina, M. Y. (2012), Professiya «tyutor» [Profession "tutor"], «SFKofis», Moscow-Tve,Russia.

3. Osadchyi, V. V. (2012), Systema informatsiinotekhnolohichnoho zabezpechennia profesiinoi pidhotovky maibutnikh uchyteliv $v$ umovakh pedahohichnoho universytetu [The system of informational and technological support for the training of future teachers in the conditions of a pedagogical university], Vyd. budynok MMD, Melitopol, Ukraine.

4. Gordon, E., Morgan, R. R., O’Malley, Ch. J., Ponticell, J. (2007), The tutoring revolution. Applying Research for Best Practices, Policy Implications, and Student Achievement, R\&L Education, New York, USA.

5. Kitchens, J. C. (2012), The Postdisciplinarity of Lore: Professional and Pedagogical Development in a Graduate Student Community of Practice. Ph.D. thesis. Georgia State University, Atlanta, 164 p.

6. Herasymenko, L. V. (2015), "Ideia indyvidualizatsii navchannia v teorii P. Kapterieva" [Individualization of Kapterev's didactics], Transactions of Kremenchuk Mykhailo Ostrohradskyi National University. Series «Pedagogical sciences», no, 1 (2), pp. 24-31.

7. Ortynskyi, V. L. (2009),Pedahohika vyshchoi shkoly [Pedagogy of higher education], Tsentr uchbovoi literatury, Kyiv, Ukraine.
8. Turkot, T. I. (2011), Pedahohika vyshchoi shkoly [Pedagogy of high school], Kondor, Kyiv, Ukraine.

9. Rybalko, L. S. (2008), Akmeolohichni zasady profesiino-pedahohichnoi samorealizatsii maibutnoho vchytelia [Acmeological Foundations of ProfessionalPedagogical Self-realization of Prospective Teacher], Extended abstract of Doctor's thesis. H.S. Skovoroda Kharkiv National Pedagogical University, Kharkiv, 44 p.

10. Zjazjun, I. A. (2008), Filosofija pedaghoghichnoji diji [Philosophy of pedagogical action], Vyd. vid. ChNU imeni Bohdana Khmelnytsoho, Cherkasy,Ukraine.

11. Tsetsorina, T. A. (2002), Organizatsiya obrazovatelnogo protsessa $v$ shkole na osnove resursnogo podkhoda [Organization of the educational process in the school based on the resource approach], Ph.D. thesis, Belgorod State University 6 Belgorod, $172 \mathrm{p}$.

12. Sysoieva, S. O. (2014), Metodolohiia mizhdystsyplinarnykh doslidzhen u sferi osvity [Methodology of Interdisciplinary Research in Education], Kyiv, Ukraine.

13. Sergeyeva, V. P. (Ed.) (2016), Tyutor v obrazovatelnom prostranstve [Tutor in the educational space], Infra-M, Moscow, Russia.

14. Osadcha, K. (2017), "Ohliad zarubizhnoho dosvidu formuvannia tiutorskoi kompetentnosti" [Review of foreign experience in the formation of tutor competence], Profesiina pidhotovka fakhivtsia v konteksti potreb suchasnoho rynku pratsi. Materialy II Vseukrainskoi naukovo-praktychnoi Internet-konferentsii [Professional training of a specialist in the context of the needs of the modern labor market. Materials of the II AllUkrainian Scientific and Practical Internet Conference], Vinnytsya, February 28, 2017, pp. 188-191. 